\title{
Article
}

\section{Determining the Effects of Nanonutrient Application in Cabbage (Brassica oleracea var. capitate L.) Using Spectrometry and Biomass Estimation with UAV}

\author{
Izar Sinde-González ${ }^{1,2}{ }^{(D}$, Josselyn Paola Gómez-López ${ }^{3}$, Stalin Alejandro Tapia-Navarro ${ }^{3}$, Erika Murgueitio ${ }^{3}$, \\ César Falconí ${ }^{4}$, Fatima L. Benítez ${ }^{5}$ (D) and Theofilos Toulkeridis ${ }^{3, *(D)}$
}

1 Grupo Geoespacial, Departamento de Ciencias de la Tierra, Universidad de las Fuerzas Armadas ESPE, Sangolquí 171103, Ecuador; iisinde@espe.edu.ec

2 Departamento de Ingeniería Agroforestal, Universidad de Santiago de Compostela, 27002 Lugo, Spain

3 Departamento de Ciencias de la Tierra, Universidad de las Fuerzas Armadas ESPE, Sangolquí 171103, Ecuador; jpgomez6@espe.edu.ec (J.P.G.-L.); satapia4@espe.edu.ec (S.A.T.-N.); esmurgueitio@espe.edu.ec (E.M.)

4 Departamento de Ciencias de la Vida, Carrera de Ingeniería Agropecuaria, Universidad de las Fuerzas Armadas ESPE, IASA I, Sangolquí 171103, Ecuador; cefalconi@espe.edu.ec

5 Institute of Geography, Universidad San Francisco de Quito, Cumbayá 170157, Ecuador; lbenitez@usfq.edu.ec

* Correspondence: ttoulkeridis@espe.edu.ec

check for updates

Citation: Sinde-González, I.; Gómez-López, J.P.; Tapia-Navarro, S.A.; Murgueitio, E.; Falconí, C.; Benítez, F.L.; Toulkeridis, T Determining the Effects of Nanonutrient Application in Cabbage (Brassica oleracea var. capitate L.) Using Spectrometry and Biomass Estimation with UAV. Agronomy 2022, 12, 81. https://doi.org/10.3390/ agronomy12010081

Academic Editor: Baskaran Stephen Inbaraj

Received: 15 November 2021

Accepted: 28 December 2021

Published: 30 December 2021

Publisher's Note: MDPI stays neutral with regard to jurisdictional claims in published maps and institutional affiliations.

Copyright: (C) 2021 by the authors. Licensee MDPI, Basel, Switzerland. This article is an open access article distributed under the terms and conditions of the Creative Commons Attribution (CC BY) license (https:// creativecommons.org/licenses/by/ $4.0 /)$.

\begin{abstract}
Geospatial technologies are presented as an alternative for the monitoring and control of crops, as demonstrated through the analysis of spectral responses (SR) of each species. In this study, it was intended to determine the effects of the application of nanonutrients ( $\mathrm{Zn}$ and $\mathrm{Mn}$ ) in cabbage (Brassica oleracea var. capitate L.) by analyzing the relationship between the vegetation indices (VI) NDVI, GNDVI, NGRDI, RVI, GVI, CCI RARSa and the content of chlorophyll (CC), from two trials established in the field and in the greenhouse, together with the calculation of dry biomass production in the field through the use of digital models and its further validation. The results indicated that for greenhouse experiments no significant differences were found between the VIs in the implemented treatments, rather for their phenological states. Whereas in the field assays it was evidenced that there were significant differences between the VIs for the treatments, as well as for the phenological states. The SR issued in the field allowed the evaluation of the behavior of the crop due to the application of nanonutrients, which did not occur in the greenhouse, in the same way. The SR also enabled the spectral characterization of the crop in its phenological states in the two trials. All this information was stored in a digital format, which allowed the creation of a spectral library which was published on a web server. The validation of the dry biomass allowed, by statistical analysis, the efficiency of the method used for its estimation to be confirmed.
\end{abstract}

Keywords: UAV; nanonutrients; vegetation indices; spectral response; biomass

\section{Introduction}

Nowadays, precision agriculture is an innovative approach developed within the management of agricultural production systems, as it allows the analysis and monitoring of crops, as well as production factors such as seeds, fertilizers, water control, among others [1-5]. The use of remote sensors, geographic information systems, global positioning systems, and artificial vision systems is having a growing influence and impact on farm management to improve yields, reduce costs and use resources efficiently, generating sustainable agriculture [6-12]. Therefore, the use of these tools in Ecuador is fundamental for the sustainable management of crops, providing solutions to the main challenges of the agricultural sector. These may include the scaling up or massification of agroecology for food production such as vegetables, fruits, and medicinal plants, and also the identification of crops and vegetables in large plots with a higher spatial and temporal resolution, the 
availability of nutrients and water, the disease distribution, the types of pests and weeds, and the considerable use of agrochemicals and fertilizers [13,14].

On the other hand, Nanotechnology refers to the manipulation of matter at a nanometric level of 1-100 nm. Theoretically, nanomaterials such as nanoparticles, nanonutrients, and nanofertilizers are able to be developed based on any chemical substance and plant extract [15-18]. This type of technology has several applications in agricultural systems and has shown a great potential in precision agriculture to improve the ability of plants to absorb nutrients [19], reduce the presence of pests, and increase the productivity of crops [20-23]. Nanonutrients are encapsulated micronutrients that improve the nutritional quality of crops due to their design and composition. They offer a slow-release of nutrients over an extended period, giving crops more time to uptake them, avoiding the repeated application of conventional agrochemicals, and reducing adverse effects on crops, plants, and the environment $[24,25]$. The Brassicaceae family includes many common vegetable crops such as cabbage, broccoli, cauliflower, and kale. Cabbage Brassica oleracea var. capitate is the most cultivated vegetable worldwide [26,27]. By 2007, there were about 3.09 million hectares of cabbage in production globally, with a total production of 69.18 million tons [28-30]. Due to its extensive consumption worldwide, it is considered one of the crops that contributes to agricultural diversification, generation of labor force, and reduction of imports [31,32]. Due to its high content of iron and chlorophyll, it helps in the treatments of depression, insomnia, exhaustion, and anxiety [33-35].

Unmanned Aerial Vehicles (UAV) are remotely or autonomously controlled airplanes or multirotors that can follow a pre-programmed flight line operating outside of the internal navigation system [36-39]. The use of UAVs and drones to capture high-resolution aerial images has numerous advantages over manned aircraft and satellites. UAVs provide a better quality in map creation, can penetrate complex and inaccessible areas, and operate locally $[40,41]$. In this sense, drones offer an infinity of possibilities within agriculture. For instance, they can fly over crops of several hectares quickly, capturing information with adequate detail and great precision, they allow the conditions of the land to be known, the state and development of the different crops, and the water regime and environmental conditions such as temperature [42,43]. In addition, the economical aspect of the use of UAV compared to other similar tools has been recently evaluated and demonstrated to be extremely efficient [12,44].

One of the most important functions within agriculture is that this type of equipment allows the detection and location of pests and diseases in a preliminary way. Thus, farmers can make decisions to reduce the use of agrochemicals, save time, reduce overall cost in farm production, and secure high-quality crops. These devices are also able to send photographs and even videos in real time to the owner or to a center where the state of the crops is observed [45].

Spectral data can contribute to the understanding of vegetation attributes and characteristics based on the interaction of electromagnetic radiation with the physicochemical properties of vegetation [46]. The spectral response of vegetation is determined by the chemical and morphological characteristics of the surface of the organs or leaves. In the visible part of the spectrum $(450-750 \mathrm{~nm})$, the spectral characteristics of vegetation are controlled by the photosynthetic process (absorption), whereas in the near-infrared region (800-1700 nm) they are controlled by the internal structure of the leaves where the incident energy can be reflected between $40 \%$ to $50 \%$, depending on the health or type of vegetation $[47,48]$. Generally, this information is registered and classified in spectral libraries that aim to facilitate the identification, monitoring, and follow-up of agricultural coverage [49].

The spectral response can be analyzed by using several vegetation Indexes (IV), such as the Normalized Difference Vegetation Index (NDVI), green band (GNDVI), Normalized Green-Red Difference Index (NGRDI), Regulatory volume increase (RVI), global vegetation index (GVI), chlorophyll content index (CCI), or ratio analysis of reflectance spectra-chlorophyll a (RARSa). These indexes are quantitative measurements based on reflectance values as a function of wavelengths, which are used to measure the amount of 
biomass, plant vigor, leaf area, and amount of nutrients through mathematical operations of the spectral values [50-60]. Among these, NDVI is the most well-know and used index to study the radiometric behavior of vegetation. It is related to the photosynthetic activity and the leaf structure of the plants, allowing for vigor and greenness detection [61].

Other agronomic variables capable of being used to estimate the proper development of a crop is the dry biomass. Some studies have used UAV to estimate biomass based on the correlation of the crop height with field samples. However, other studies estimate biomass by calculating the volume between digital models of the crop and terrain and the calculation of a density factor [62-66].

In this context, the objective of this research was to determine the effects of the application of nanonutrients ( $\mathrm{Zn}$ and $\mathrm{Mn}$ ) in cabbage crops (Brassica oleracea var. Capitata L.) by using geospatial technologies as an alternative method for monitoring and control. Therefore, the use of high-sensitivity UAV platforms and remote sensors was proposed.

\section{Study Area}

The project was carried out under two production systems: greenhouse covered and open-field conditions. A glazed greenhouse was considered for conducting the trial A of the project. It is located at the Agricultural campus (IASA I) of the Fuerzas Armadas University-ESPE, close to Sangolquí city (See Figure 1). The trial B of the project was conducted in an open-field area of $274 \mathrm{~m}^{2}$ inside of the Agro-Hidropónica San Antonio Cia. Ltda. farm which is located $25 \mathrm{~km}$ from trial A.

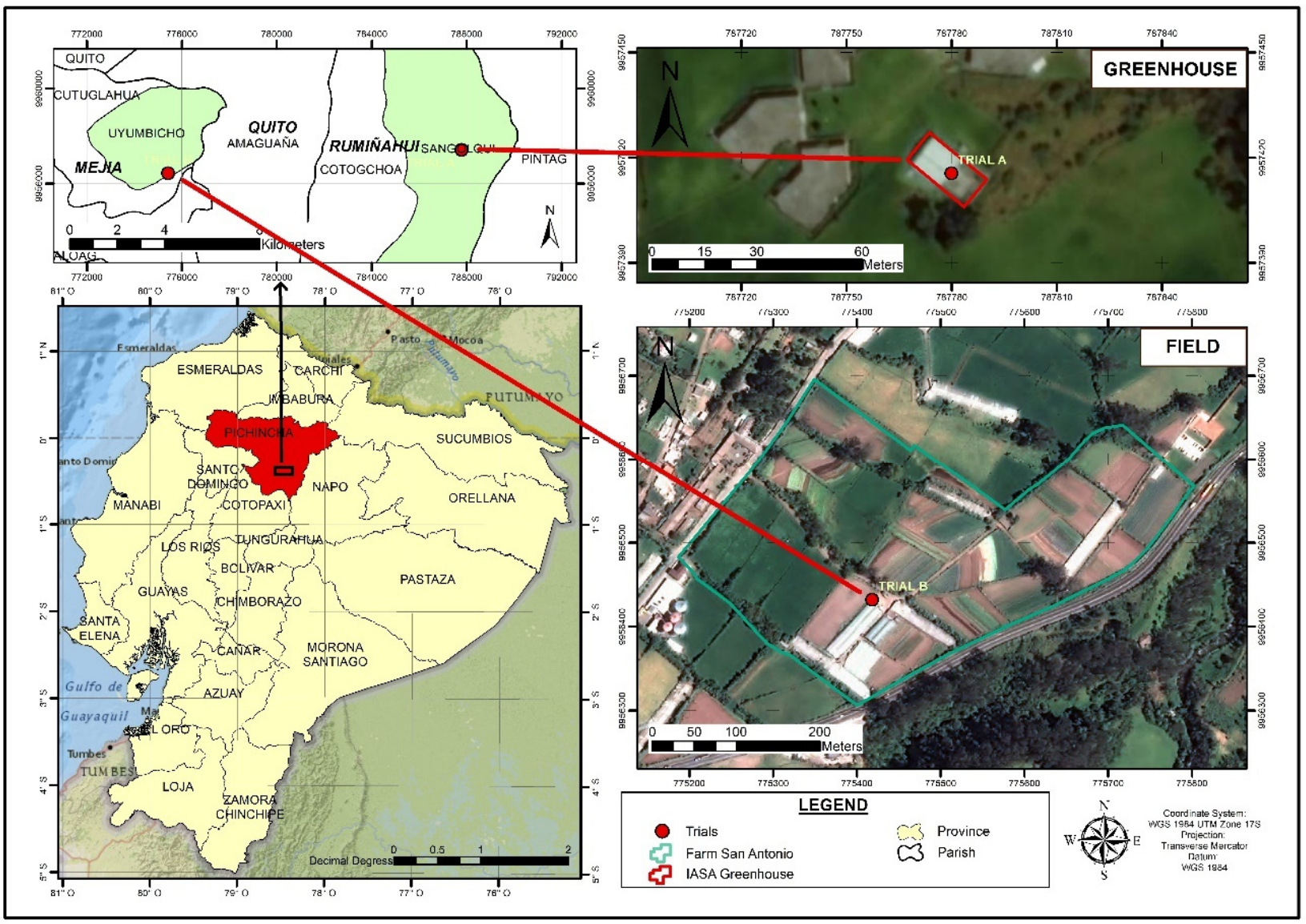

Figure 1. Location of the two experimental trials under greenhouse and open-field conditions.

\section{Materials and Equipment}

The equipment used to capture spectral data was the PSR-1100 Field Portable Spectroradiometer that works in the range of 320-1100 nm, which has a spectral resolution of $3 \mathrm{~nm}$ and a width of $1.5 \mathrm{~nm}$. The CCM-200 Plus equipment from the Opti-sciences brand was 
used to capture Chlorophyll Content (CC). It uses optical transmittance of 653 and $931 \mathrm{~nm}$ with a measurement area of $9.53 \mathrm{~mm}$ diameter circle, having also a detector formed with silicon photodiodes with an integral absorbance amplifier. In order to estimate biomass content, a Smartphone (mobile application) and a DJI Mavic Pro drone were used at a relatively low cost. The weight of the drone is about 1.64 pounds with a speed of up to $61.2 \mathrm{~km} / \mathrm{h}$ and a maximum height of 5000 meters above sea level. It has an RGB camera with a 1/2.3" sensor (CMOS) with a lens of approximately $35 \mathrm{~mm} \mathrm{f} / 2.2$ of $12.71 \mathrm{MP}$ (See Figure 2). Trimble R8 dual frequency equipment was used to collect control points for geometry calibration.

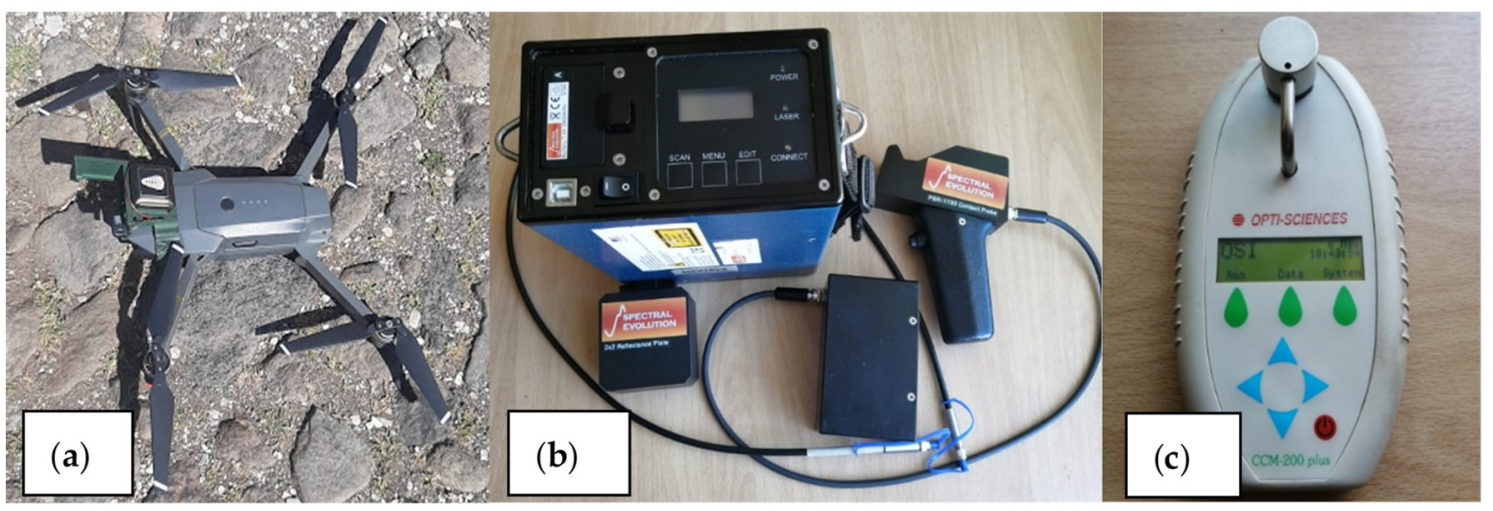

Figure 2. Equipment used in the project. (a) DJI Mavic Pro 1 UAV; (b) PSR-1100 Field Portable Spectroradiometer; (c) CCM-200 plus chlorophyll content meter.

Spectral and CC data were processed and analyzed through the use of software namely Excel 2013 spreadsheet, IBM SPSS Statistics 25, and Infostat. Photogrammetric image processing was conducted with the Pix4D Mapper software that allows the generation of 3D and orthomosaic models. The treatment and debugging of the point cloud (lidar data) was performed in the ERDAS Imagine software and the subsequent calculation of surface volumes was generated with the Global Mapper software.

\section{Methodology}

The methodology applied in the current study comprises three main steps. The first is associated with the experimental design and sample selection, and also with the application of nanonutrients and chelates in cabbage plants under both greenhouse and open-field conditions. The second corresponds to the collection of spectral information of the plants such as chlorophyll content, followed by data processing that includes indices calculation biomass estimates. The final stage focuses on the generation of the spectral library (See Figure 3).

\subsection{Initial Assessment}

Chelates and nanonutrients were applied through the use of an aqueous solution in the following concentrations: Treatment 2 (T2) low concentration chelates $(1.25 \mathrm{~g} / \mathrm{L})$; Treatment 3 (T3) high concentration chelates (1.88 g/L); Treatment 4 (T4) low concentration nanonutrients (270 ppm); Treatment 5 (T5) nanonutrients in high concentration (540 ppm). The product was applied $72 \mathrm{~h}$ before each sampling by means of foliar spraying. Treatment 1 (T1) corresponds to the control unit. The treatments were repeated three times (15 units in total) and distributed randomly for each experimental unit (See Figure 4). 


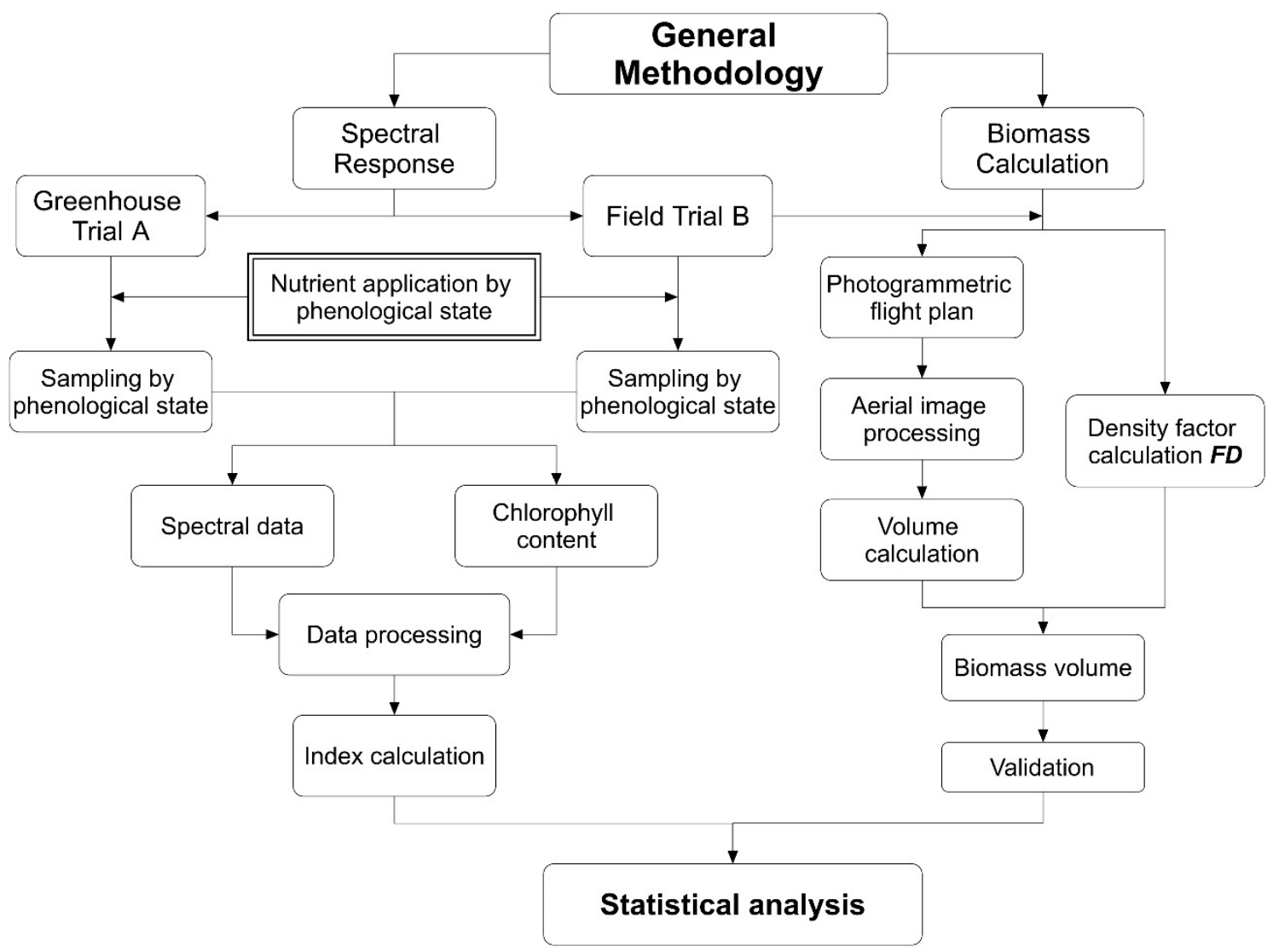

Figure 3. Research methodological scheme of the current study.

The sample design for the trials is based on the most Brassicas phenology. These phenological stages have characteristics of the crop. For sampling, periods of 15 days were considered from the establishment of the crop, with a total of four samplings per trial (Table 1).

Table 1. Sampling planning according to the phenological stage.

\begin{tabular}{cccc}
\hline \multirow{2}{*}{ Sampling } & Phenological State & Trial A & Trial B \\
\cline { 3 - 4 } & & Days after Sowing (das) \\
\hline First sampling & Establishment & 31 & 32 \\
Second sampling & Vegetative development & 38 & 36 \\
Third sampling & Head preforming & 52 & 50 \\
Fourth sampling & Head formation & 66 & 65 \\
\hline
\end{tabular}

The size of the sample within an experimental design is a fundamental pillar if it is expected to find any difference between treatments [67]. In this study, we selected ten observations (plants) in each experimental unit (thirty observations per treatment) in the open-field trial, whereas in the greenhouse trial, we selected three observations per experimental unit (nine observations per treatment). The number of data collected for each observation was three, both for field and greenhouse. 


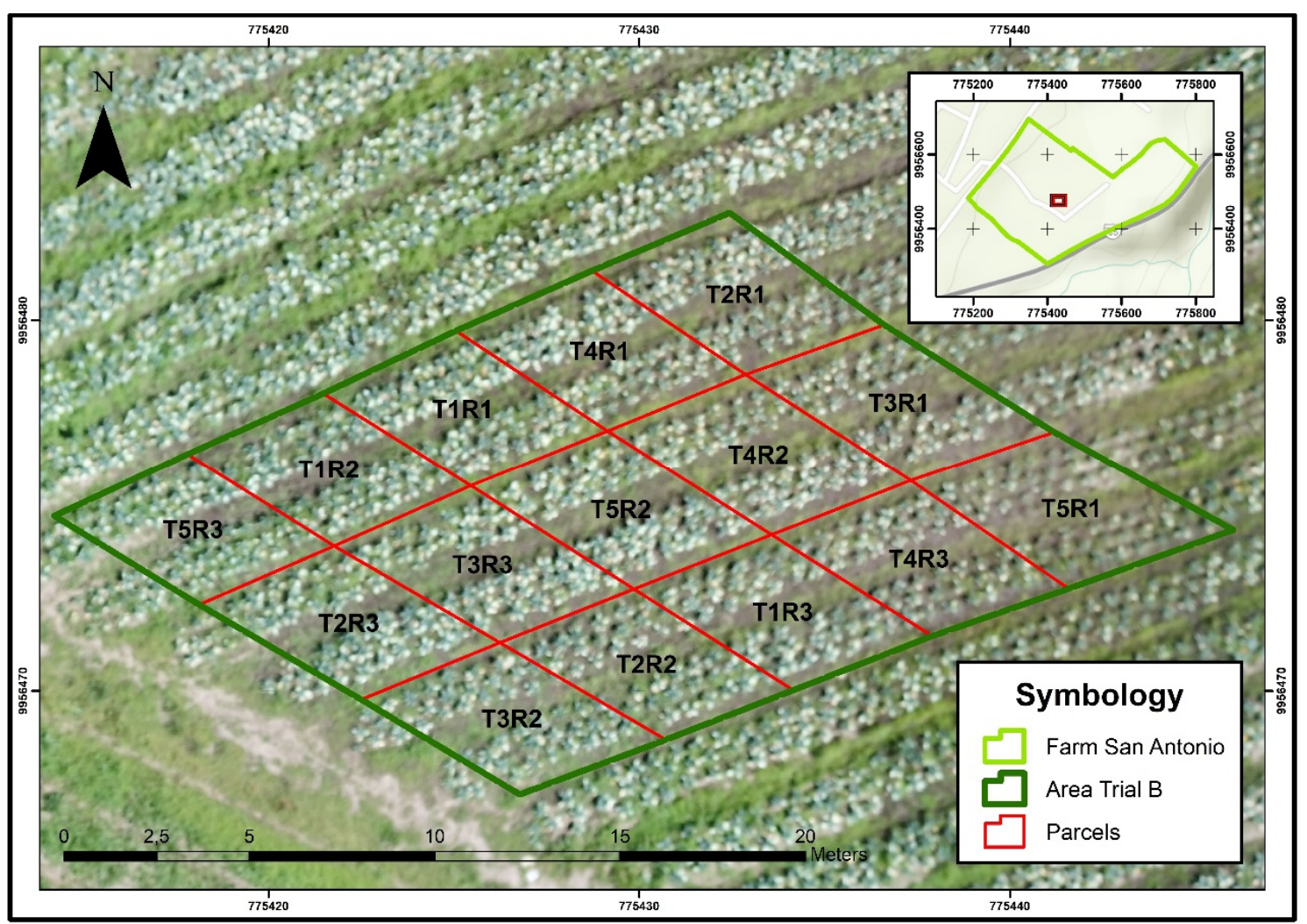

Figure 4. Treatments distribution of Trial A.

\subsection{Generation of Information}

The portable field spectroradiometer PSR-1100 was used to collect spectral information related with reflectance in both field and greenhouse systems. Some parameters were set up in the equipment configuration. Subsequently, the equipment was calibrated using black and white calibration plates obtaining reflectance measures of $0 \%$ and $100 \%$, respectively. Previous knowledge about spectral responses of analyzed targets is required before spectral data acquisition to obtain data with the least amount of error, representing the reality of the analyzed object. The data collection procedure is illustrated in Figure 5.

For collecting chlorophyll content (CC) values, in the two trials, the Opti-sciences CCM-200 Plus equipment was used. Like the previous procedure, the equipment also requires prior calibration before data collection, this process is automatically requested by the equipment. In open-field conditions, a clean-safe place was designed to keep the spectroradiometer and chlorophyll meter away from residues.

\subsection{Data Processing}

Once the process of obtaining and capturing spectral and CC data was completed, the information collected was processed. For the spectral information, the data was located inside the collector and was downloaded as individual files in .sed format. Output files contain detailed information about the sampling such as date, time, label of each observation, GPS coordinates, and wavelengths $(\mathrm{nm})$ with their respective radiance and reflectance $(\%)$ values. We obtained the average of the three collections for each observation. 


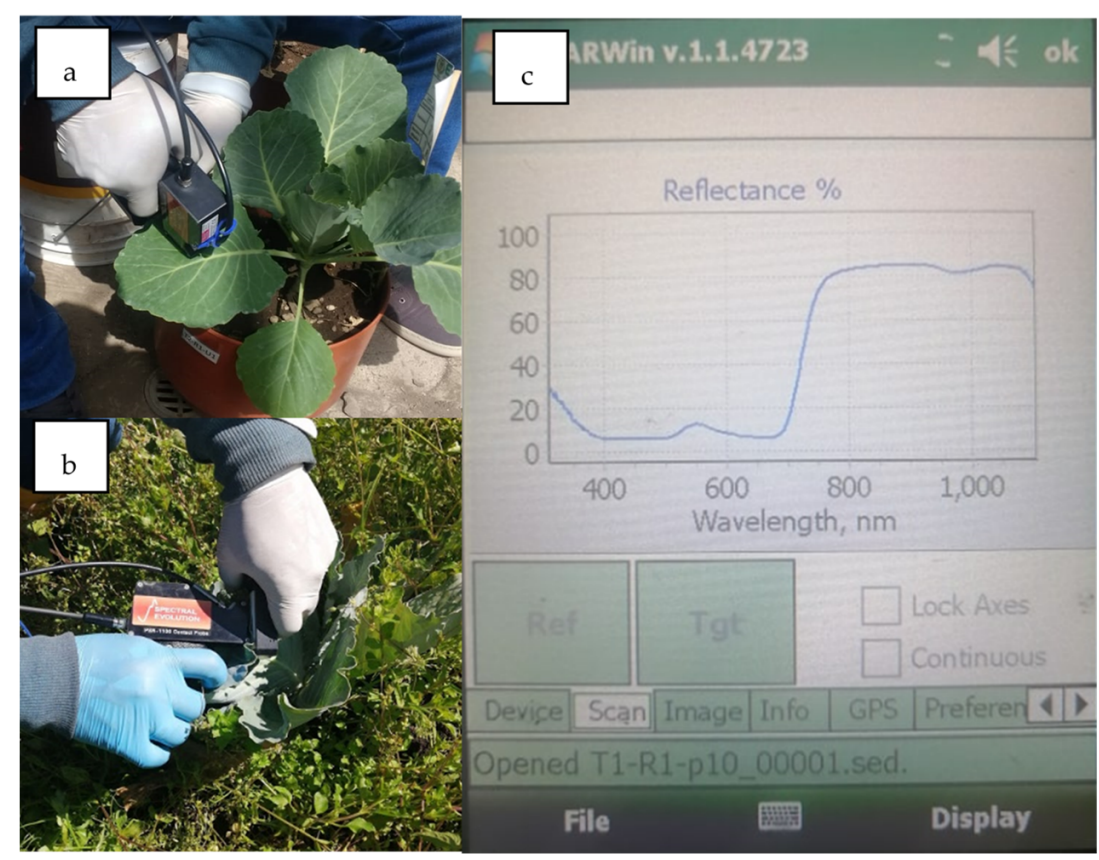

Figure 5. Data collection: (a) In greenhouse; (b) In field; (c) Software interface with spectral signature.

For the calculation of indices, the green $(560 \mathrm{~nm}$.$) , red (630 \mathrm{~nm}$.) and near infrared (850 nm.) (NIR) bands were considered. The minimum and maximum wavelengths are those that were used for the calculation of the VIs based on [68]. Once the values to be used had been determined, the VIs, such as the NDVI, GNDVI, NGRDI, RVI, GVI, CCI, RARSa, generated the corresponding reflectance values [69-74].

For the biomass (only Trial B), in the case of commercial cultivation, two flights were conducted with an UAV. The data collected was used as input for the generation of surface models, point cloud, and orthomosaic information. This data was used to estimate biomass volume. The volume is calculated through the difference between the digital terrain model (DTM) and the digital crop model (DCM) (See Figure 6), without the need to carry out an individual characterization of each of the observations raised for the trial. After this, a density factor was calculated. We used a destructive method for its estimation since it considers physical aspects such as diameter, height, and dry weight [65]. A similar procedure was conducted in the validation area and after this, a " $t$ " test was performed for its statistical validation.

\subsection{Spectral Library}

The spectral library is still within the implementation phase of this research, having only treatment 1 (T1, control) in its different phenological stages. The spectral responses of this treatment, collected in the greenhouse and in the field, previously treated, was stored in .csv files, which contain the record of the spectral signatures by repetition and sampling. This information is available for later studies in a database in Language R. This is publicly accessible through a web page, where users will have the script and the base information (metadata). 
(a)

(b)
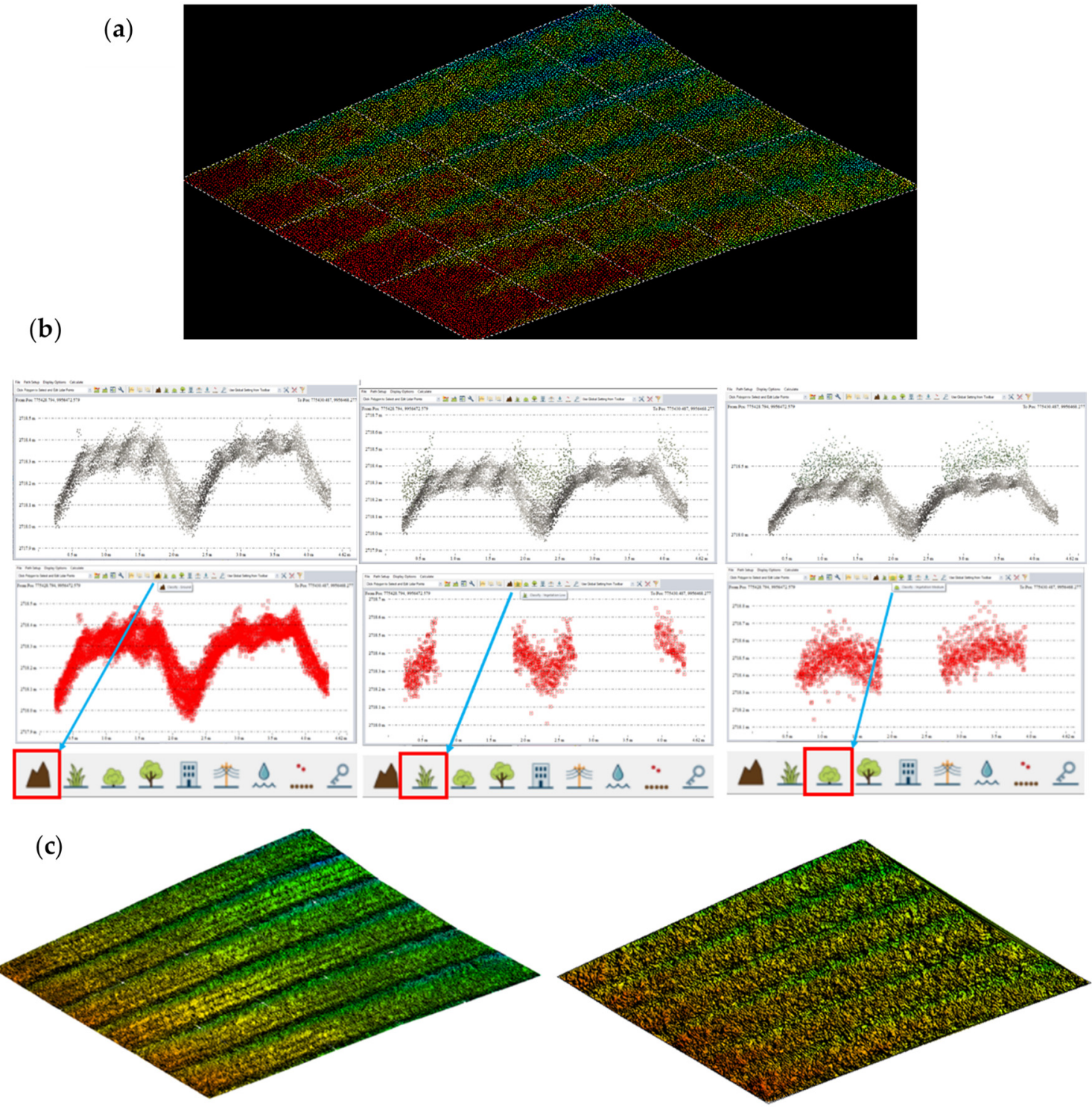

Figure 6. Product generation process: (a) Point cloud partition; (b) Point cloud depuration of ground, weed and crop points; (c) DTM vs DCM.

\section{Results}

5.1. Characterization of Treatments and Phenological Stages by Vegetation Index (Spectral Data) 5.1.1. Results of Trial A

There were no significant differences among treatments, with a 5\% level of significance which is why the null hypothesis is accepted. The spectral response is not efficient to find significant differences between treatments during the phenological development of cabbage. However, we found that spectral responses were efficient to find significant differences between phenological stages during the development of the cabbage crop (Table 2). 
Table 2. Statistical values for phenological states of trial A (left columns), for treatments (central columns) and phenological states of trial B (right columns).

\begin{tabular}{|c|c|c|c|c|c|c|}
\hline Index & $\mathbf{F}$ & $p$-Value & $\mathbf{F}$ & $p$-Value & F & $p$-Value \\
\hline NDVI & 22.59 & $<0.0001 *$ & 5.813 & $0.0001 *$ & 156.517 & $<0.0001 *$ \\
\hline GNDVI & 15.04 & $<0.0001$ * & 5.948 & 0.0001 * & 176.667 & $<0.0001$ * \\
\hline NGRDI & 75.33 & $<0.0001 *$ & 3.598 & $0.00066^{*}$ & 29.151 & $<0.0001 *$ \\
\hline RVI & 22.01 & $<0.0001$ * & 5.737 & $0.0002 *$ & 152.650 & $<0.0001 *$ \\
\hline GVI & 16.60 & $<0.0001$ * & 5.642 & $0.0002 *$ & 174.657 & $<0.0001 *$ \\
\hline CCI RARSa & 40.55 & $<0.0001 *$ & 6.751 & $<0.0001 *$ & 141.735 & $<0.0001$ * \\
\hline
\end{tabular}

\subsubsection{Results of Trial B}

After the analysis performed on the treatments, with a significance level of $5 \%$, it was shown statistically if there were significant differences between treatments, rejecting the null hypothesis. This means that the spectral response is efficient in finding significant differences between treatments during the phenological development of cabbage and whose results are listed in Table 3. Subsequently, the analysis for phenological states was conducted, in the same way with a significance level of 5\%. Results show that there were significant differences between phenological states, rejecting the null hypothesis. It means that the spectral response is efficient in finding significant differences between phenological stages during the development of cabbage (Table 3).

Table 3. Value of CC statistics for phenological states.

\begin{tabular}{ccl}
\hline Index & F & $p$-Value \\
\hline CC $($ phenological states, trial A) & 22.51 & $0.0001 *$ \\
\hline CC (treatments) & 5.64 & $0.0002 *$ \\
\hline CC (phenological states, trial B) & 3.28 & $0.0275 *$ \\
\hline * Statistical significance $p$-value $<0.05$. & &
\end{tabular}

\subsection{Content of Chlorophyll (CC)}

\subsubsection{Results of Trial A}

After performing the statistical analysis with a $5 \%$ level of significance, it was possible to find that there were no significant differences by treatment, accepting the null hypothesis. This means, that the chlorophyll content is not efficient in finding significant differences between treatments during the phenological development of cabbage. Despite this, results show differences by phenological states (Table 3), accepting the alternative hypothesis. Chlorophyll content is efficient in finding significant differences between phenological stages during the development of the cabbage crop.

\subsubsection{Results of Trial B}

Parallel to the previous analysis, CC analysis shows the existence of differences between treatments at a significance level of $5 \%$ (Table 3), accepting the alternative hypothesis, where the content of chlorophyll is efficient in finding significant differences among phenological states during the development of the cabbage crop.

Similarly, the CC analysis for phenological states demonstrated that there were significant differences between states and that is how the alternative hypothesis was accepted. Thus, chlorophyll content is efficient in finding significant differences between phenological states during the development of the cabbage crop.

\subsection{Validation of Biomass}

For data validation in trial B, a comparative analysis was performed between this trial and the validation zone. In this study, we decided to take the data from the control (T1) 
to make the comparison. The following table lists the results of the t-test for the biomass means with a significance level of $5 \%$ and solves the null hypothesis for validation of biomass data (Table 4). The population mean of the biomass volume of the crop in trial $\mathrm{B}$ is equal to the population mean of the biomass volume in the validation zone. The distribution of the validation samples is indicated in Figure 7.

Table 4. Comparison of means t-test for biomass validation.

\begin{tabular}{|c|c|c|}
\hline \multirow{2}{*}{$\begin{array}{c}\text { Variable } \\
\text { Zone }\end{array}$} & \multicolumn{2}{|c|}{ Biomass } \\
\hline & Trial B & Validation Zone \\
\hline Mean & 0.790022 & 0.78184 \\
\hline Observations & 3 & 4 \\
\hline Variance & 0.28301 & 0.004 \\
\hline Difference of means & & \\
\hline $\mathrm{t}$ & & \\
\hline Degrees of freedom & & \\
\hline$p$-value & & \\
\hline
\end{tabular}

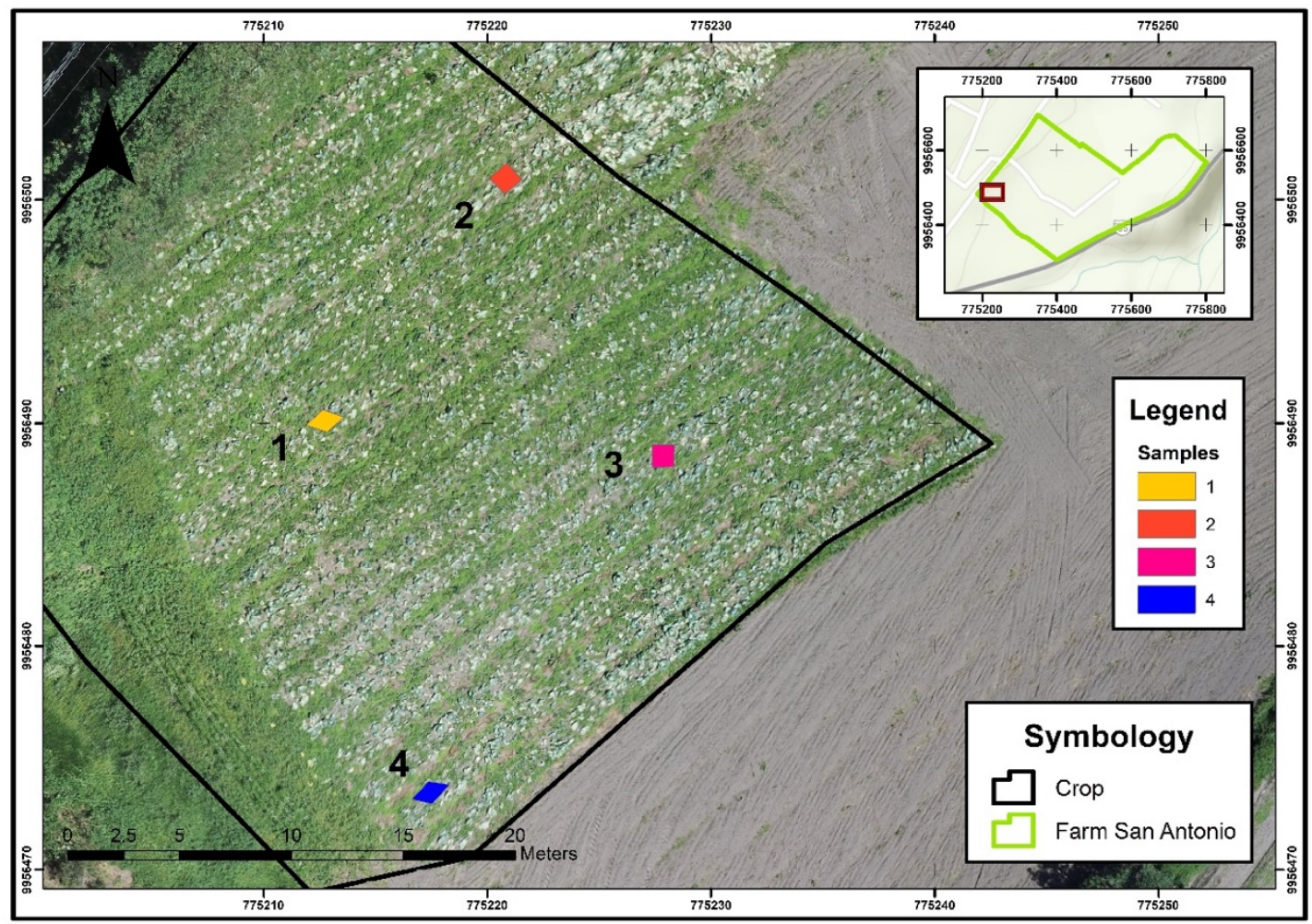

Figure 7. Sample distribution for validation in trial B.

\subsection{Spectral Library}

The spectral library was located on a public and open access web server (RPubs). All the spectral responses (signatures) collected during the project development were upload to the server. This will allow users to discriminate the different phenological stages and cultivation conditions. In addition, the basic functions of the exploratory analysis of the data and the spectral responses of the culture are provided in each repetition and phenological state obtained in the R and RStudio software using the RMarkdown language. In Figure 8, a sample of the spectral signatures is shown for commercial and controlled crops. 

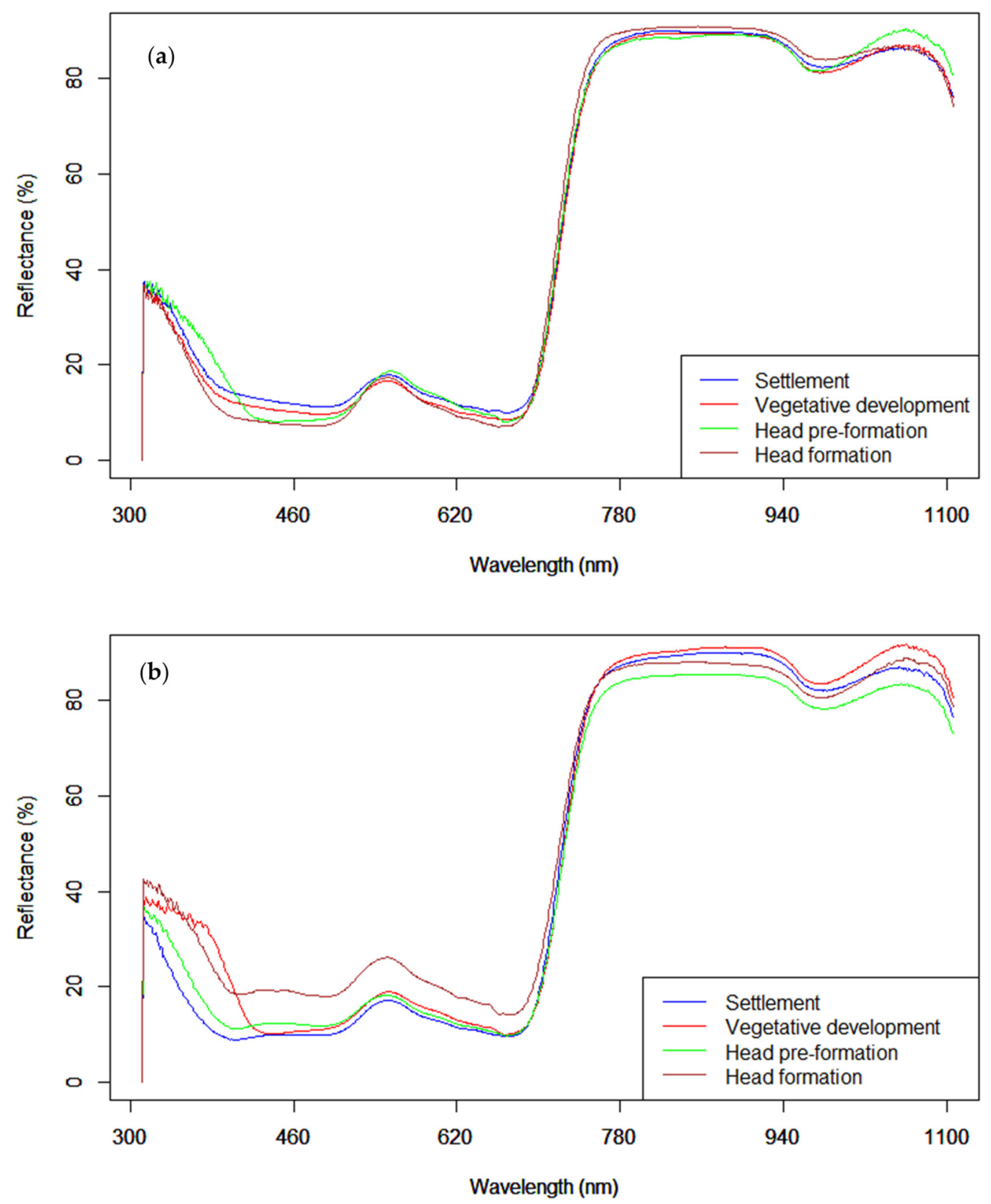

Figure 8. Spectral responses in different phenological stages: (a) Commercial crop; (b) Controlled crop.

\section{Analysis and Discussion}

\subsection{Spectral Data}

6.1.1. Analysis of Trial A

During the development of the crop, the values of the NDVI and RVI indices show similar behavior, where it is evidenced that the phenological states of vegetative development and head formation share the same range of significance, being statistically equal, while the states of establishment and preformation have a defined behavior (vegetative development and head formation), respectively. The NDVI is influenced by climatic conditions with a weak capacity to minimize the influence of soil and atmosphere [75]. Despite this, it is an adequate indicator to characterize the spatial distribution and the evolution of the state of the crops over time.

When we analyzed statistically the GNDVI and GVI indices by phenological states, it was evidenced that both indices have the same behavior. We also observed that there 
were significant differences in the states of establishment, vegetative development, and head formation, while the phenological state of head preformation did not have a defined significance range since it is able to behave statistically in either form. On examining the values, a significant increase from the first to the second phenological stage was evidenced. However, there was a decrease in this value within the rest of the states.

After conducting Fisher's LSD test, we observed that the NGRDI increases considerably as the crop develops and therefore allows indication that it is possible to differentiate the development of this crop in its different phenological stages with this index. This is consistent with previous research where the indices based on the visible spectrum bands such as GLI and NGRDI have a high correlation with CC, amount of biomass and therefore leaf area, compared to the indices that use the infrared band, as is the case of RVI and NDVI [58].

The CCI RARSa demonstrates that the phenological state of establishment presents the highest value, then the value of the index decreases in the phenological stage vegetative development and has a slight improvement in the preformation state of the head. However, there is no evidence of an increase in CC in the state of head formation. That is, the culture cannot be distinguished spectrally by this index between the three mentioned states. This agrees and coincides with other studies, where it has been highlighted that the CCI RARSa had an inverse relationship to the phenological development of the Phaseolus vulgaris L. crop, where a higher CC was obtained during the initial cultivation stages, and a lower $\mathrm{CC}$ in the flowering and sheathing stages [76]. Because the chlorophyll molecule absorbs radiation at $680 \mathrm{~nm}$, young or senescent leaves have a lower CC and consequently the radiation is reflected, while, in the flowering and sheathing stages where the leaves have higher CC, the radiation is absorbed.

\subsubsection{Analysis of Trial B}

The results of the spectral response for treatments have a variability in the behavior of the VIs. For NDVI and RVI there is a significant difference between treatment 5, 2, and 3, while for treatment 4 it was demonstrated that there is no significant difference between it and treatment 5 and 2, In the same way, in treatment 1 it was observed that there is no difference between it and treatment 2 and 3. Within the analysis for these two indices, the existence of improved results of the chelates at high concentration (T3) at the spectral level is found, compared to control. On the other hand, treatments 2, 4, and 5 indicated low levels compared to control. This coincides with other studies that demonstrated high correlations between the relationship of NIR and RED (NDVI) with the foliar biomass of crops [77]. The relationship between NDVI and other aspects such as vigor, chlorophyll, and greenery of the plant are also given [78]. Therefore, the treatment exposed to chelates at high concentration (T3) indicates an improvement for cabbage, but a notable deterioration before the application of nanonutrients at high and low concentration (T4 and T5) due to some chemical toxicity within the solution or stress caused by the surface, size, or shape of particles [79].

In a slightly similar way, the GNDVI and GVI in comparison between treatment 5 is significantly different from treatments 1 and 3. These last two treatments together with treatment 2 have the same variety of significance range, so statistically they are similar. Hereby, the green band and the chlorophyll-a content are proportional, while the crop has a loss of pigmentation by providing nutrients in the form of nanoparticles, be it of any concentration. However, the effect of the application of chelates at low or high concentration is also maintained or in this case is inhibited [80].

In NGRDI, a completely different behavior is demonstrated compared with the previous evaluated indices. For the set of treatments 5, 2 and 4, there are no differences, while within the analysis of treatment 1 there is evidence of a similarity of their means for both the mentioned set and the treatment 3 . Treatment 3 is significantly different from its peers and its values stand out among them, thus confirming a slight improvement in the culture, even though they share a statistically significant range with the control. The NGRDI evaluates 
the leaf area as well as the greenness of the plant as mentioned. Therefore, it is possible to deduce that the treatments reduced the growth of the crop in a small proportion [81].

The CCI RARSa index is similar to the NDVI index, but with a small variation within the order of treatments. In this way, the data indicate that, for this index, there is a significant difference between treatment 3,2 , and 5 , while for treatment 1 it was demonstrated that there is no significant difference between it and treatment 3 and 2, and equally thus, in treatment 4 it was observed that there is no difference between it and treatment 2 and 5 . Within what has been described, for CCI RARSa, the treatments behaved inversely to the IV previously studied, thus, treatment 5 indicates increase in chlorophyll A pigment. In other words, high concentration of nanonutrients had a positive effect on the crop, as well as low concentration, but high or low concentration chelates failed to improve pigment content. The sensitivity of the CCI RARSa depends clearly on the reflectance and radiation emitted by the culture at the wavelengths of 680 and $800 \mathrm{~nm}$, Also, as previously mentioned in the analysis of trial A for phenological states, it is precisely at $680 \mathrm{~nm}$ where the chlorophyll-a absorbs a greater amount of radiation. Hereby, the maximum red absorption reflectance sensitivity of chlorophyll-a is at $670 \mathrm{~nm}$ [80].

The analysis of phenological states for the spectral response, have a similar behavior for the Vis NDVI, GNDVI, RVI, and GVI. It is known that these four indices work as a function of reflectance in the infrared band, so the behavior of their averages is similar among them. By performing the analysis, it was demonstrated that the establishment stage has the highest values of each of these indices and the formation of the head the lowest. Although the values for one of the indices reflect a plant decay, they are important for the analysis of the crop. Furthermore, there exists the importance and effectiveness of the evaluation of the yield and growth of the cabbage using indices such as NDVI, GNDVI, NR (RVI), and NG (GVI) and its correlation with physical variables such as weight, diameter, height, and area [82].

The NDVI is used to detect the scope of the variability of the crop quality [83]. Additionally, the use of the NDVI formula to implement nanosensors for the detection of diseased plants and healthy ones, clearly evidences the importance that the use of radiometric or spectral data still has precision for agriculture [84]. In NDVI, the value of this index is related to the vigor, chlorophyll, and greenness of the plant. In this way and based on the average values, these characteristics of the plant tend to decrease as the crop goes through its phenological stages [78]. For the GNDVI, we have a statistically similar behavior for the states. However, if this index is a variant of the NDVI, its value is related to the amount of biomass of the crop and not that much oriented to the amount of chlorophyll-all this, due to the values of the wavelength used for its calculation. In the cases of RVI and GVI, these behave similarly to NDVI and GNDVI.

For the NGRDI, the states show an atypical behavior of their results, having as minor data the establishment, which is justifiable because it is the first phenological state of the crop and here only the first true leaves are shown $[85,86]$. Later, it was demonstrated that the vegetative development has a similarity with respect to the preformation, but a supremacy with the head formation. As evidenced in the formula for NGRDI, it uses only the bands of the visible spectrum, because it is a simple and inexpensive alternative. This is the reason why it raises the relationship between this index and the leaf area index (LAI) [87].

The values of the CCI RARSa index have a progressive behavior as the phenological stages pass. This means that the plant has a gradual improvement with respect to this VI, except for the vegetative development, which has a small supremacy with respect to the preformation of the head. The RARSa evaluates the concentrations of the photosynthetic pigments of the plants, especially for chlorophyll-a from reflectance [88]. A dynamic has been indicated between RARSa and the sowing days for beans and peach blossom by application of nitrogen, where a decreasing behavior in its values within the period of 20-60 days, and an ascending behavior after 60 days were demonstrated [67]. This 
conforms to how the cabbage crop behaves, as its RARSa values rise in the head formation, which begins at approximately 67 days.

6.2. $\mathrm{CC}$

6.2.1. Results of Trial A

When observing the behavior of CC by phenological states, it indicated that in the range of the states of establishment and vegetative development, when analyzing the values of the means there is a slight improvement between the first and second state. However, the crop improves significantly in the rest of its development. CC in plants is closely related to photosynthesis, yield, and crop development [89].

\subsubsection{Analysis of Trial B}

The analyses for treatments yielded variability in the CC, thus evidencing a greater difference between the sets of treatments 3 and 5 as well as for 1,2 and 4 where their ranges of significance vary. However, within this last set, treatments 1 and 2 are statistically similar. The behavior for CC indicates that treatment 4 obtained better results, but shares a range of significance with treatment 2 and 1 . Therefore, statistically there is no effect from the application of nutrients (nanonutrients or chelates) at low concentrations, but there is a change with respect to the treatments with high concentration (T3 and T5). From this analysis and based on the study of [90] using sorghum (Pennisetum americanum) crops, the efficacy of zinc nanoparticles in increasing chlorophyll by $24.4 \%$ is given, therefore the improvement of the cabbage crop at the CC level is evidenced. When countering this analysis, it is also fundamental to consider the toxicity, and that it might be the cause of affecting or reducing CC due to nanonutrients and chelates at high concentration [79].

On the other hand, for phenological states, the CC demonstrated differences between its phenological states. This occurred mainly between the establishment and the head preformation, being within these states, where the CC indicates a progressive behavior with a decay in the formation stage of the head. This may be a symbol of some type of direct involvement of the blade. For these first three states, a similar outcome has been reported, where a comparison was made for soybeans between the measurements performed by a radiometer and the values calculated using an RARS algorithm. Hereby, a large linear relationship was found between both forms of CC measurement [88].

\subsection{Biomass}

The biomass validation demonstrates that the method used to estimate biomass is highly effective in its calculation, as both crops had the same characteristics, in their agricultural treatment as well as in their phenological age. In a study performed on barley crops, it was mentioned that this methodology has great potential in future applications for different types of crops, mainly for the control of the vitality of crops and also in the same way to evaluate their yields [62]. Another study used LIDAR information in order to estimate the volumes of Korean pine (Pinus koraiensis Sieb. Et Zucc) stems and their biomass, applying it to different tree densities [91].

\section{Conclusions}

A sufficient amount of radiometric information was obtained in the form of spectral signatures that allowed the spectral characterization of the cabbage (Brassica oleracea var. capitata L.) in its first four phenological stages, both for the crops grown in greenhouse (trial A) and those developed in the field for a commercial crop (trial B).

Vis and CC were used as analysis parameters to determine significant differences between each of the proposed treatments and the phenological states of cabbage.

For trial A, some of the VI used were efficient to characterize spectrally the cabbage crop during its phenological development in the controlled greenhouse trial (Trial A). However, they were not efficient to identify statistically significant differences by chelate or nanonutrient treatments with respect to the control or control. The GNDVI, GVI, NDVI, 
and RVI index generated from spectral signatures presented an anomalous behavior during the growth of the crop. Therefore, we may conclude that they do not allow characterization of the cabbage crop in all its phenological stages. Despite this, the NGRDI index has a higher sensitivity to characterize spectrally the culture during its development.

The CCI RARSa index measured in this trial presented an inverse relationship to the development of the crop, this was due to the amount of absorbance and reflectance of light at the wavelength of $680 \mathrm{~nm}$, while the value acquired with the chlorophyll meter in trial A indicated that there were no differences between treatments. However, it was possible to distinguish the majority of phenological states because such value increases as the crop develops, have the maximum value at the head formation stage.

In trial B, the analysis for treatments based on spectral information (vegetation indices) indicated that there is little efficiency in the application of nanonutrients at both low and high concentration. They even demonstrated a small deterioration of the crop, while on the other hand, the application of chelates indicated similar behavior with respect to the control. Therefore, there was an inhibition of nutrients in the plant. For CCI RARSa and $\mathrm{CC}$, an improvement of the culture was obtained with the treatment of nanonutrients at low concentration, but a low effect on the application of chelates.

For phenological states, the analysis performed on the spectral information demonstrated that significant differences were found for each state. The NDVI, GNDVI, RVI, and GVI indices yielded a decline as the phenological development of the crop elapsed, which shows a high effectiveness in the detection of possible anomalies, diseases, or phenomena that affect or are directly related to the plant - this, with the support and implementation of remote sensing tools in agricultural crops. The NGRDI index, which works with waves within the visible spectrum, shows a discontinued behavior in the analysis of trial B. Therefore, it could be concluded that it is not a highly effective index in field crop analysis. The calculated CCI RARSa index and the CC value measured in the field indicate a gradual improvement of the crop at the chlorophyll level, while its phenological development advances.

The use of digital surface models to estimate the volume of biomass is evidenced to be a highly effective method in calculating this parameter, and practical when implementing it. The biomass validation conducted in the current study demonstrated that it is possible to use these types of methodologies and tools in order to calculate crop volumes in plantations with a relatively low canopy in height.

The creation of the catalog or spectral library of public access in the web environment was conducted with the $\mathrm{R}$ and RStudio software using the RMarkdown language, based on the spectral response of both tests, with their respective metadata. This was generated in order to identify and quantify the spectral behavior of this crop in its different phenological stages.

Author Contributions: Conceptualization, I.S.-G. and F.L.B.; methodology, I.S.-G. and E.M.; software, C.F.; validation, I.S.-G., C.F. and F.L.B.; formal analysis, J.P.G.-L. and S.A.T.-N.; investigation, C.F., F.L.B., J.P.G.-L. and S.A.T.-N.; resources, C.F.; data curation, I.S.-G., E.M. and T.T.; writing-original draft preparation, I.S.-G. and T.T.; writing-review and editing, T.T.; visualization, J.P.G.-L. and S.A.T.-N.; supervision, I.S.-G.; project administration, I.S.-G. All authors have read and agreed to the published version of the manuscript.

Funding: This research received no external funding.

Institutional Review Board Statement: Not applicable.

Informed Consent Statement: Not applicable.

Data Availability Statement: Data recorded in the current study are available in all Tables and Figures of the manuscript.

Acknowledgments: We are very thankful to Agro-Hidropónica San Antonio Cia. Ltda, especially to Patricia Chango for sharing with us her vast knowledge in crop management and allowing us to use the farm facilities to implement our trial. 
Conflicts of Interest: The authors declare no conflict of interest.

\section{References}

1. Garcia-Sanchez, A.J.; Garcia-Sanchez, F.; Garcia-Haro, J. Wireless sensor network deployment for integrating video-surveillance and data-monitoring in precision agriculture over distributed crops. Comput. Electron. Agric. 2011, 75, 288-303. [CrossRef]

2. Patrício, D.I.; Rieder, R. Computer vision and artificial intelligence in precision agriculture for grain crops: A systematic review. Comput. Electron. Agric. 2018, 153, 69-81. [CrossRef]

3. Gusev, A.S.; Beznosov, G.A.; Ziablitckaia, N.V.; Kholmanskikh, M.V.; Novopashin, L.A.; Denyozhko, L.V.; Sadov, A.A. An analysis of research areas in precision agriculture. Int. Trans. J. Eng. Manag. Appl. Sci. Technol. 2019, 10, 10A1D.

4. Bauer, A.; Bostrom, A.G.; Ball, J.; Applegate, C.; Cheng, T.; Laycock, S.; Rojas, S.M.; Kirwan, J.; Zhou, J. Combining computer vision and deep learning to enable ultra-scale aerial phenotyping and precision agriculture: A case study of lettuce production. Hortic. Res. 2019, 6, 70. [CrossRef] [PubMed]

5. Nyaga, J.M.; Onyango, C.M.; Wetterlind, J.; Söderström, M. Precision agriculture research in sub-Saharan Africa countries: A systematic map. Precis. Agric. 2021, 22, 1217-1236. [CrossRef]

6. Cassman, K.G. Ecological intensification of cereal production systems: Yield potential, soil quality, and precision agriculture. Proc. Natl. Acad. Sci. USA 1999, 96, 5952-5959. [CrossRef]

7. Martínez-Casasnovas, J.A.; Bordes, J. Viticultura de precisión: Predicción de cosecha a partir de variables del cultivo e índices de vegetación. Rev. Teledetección 2005, 24, 67-71.

8. Guerrero, J. Sistema de Visión Para Agricultura de Precisión: Identificación en Tiempo Real de Líneas de Cultivo y Malas Hierbas en Campos de Maíz. Ph.D. Thesis, Complutense University of Madrid, Madrid, España, 2015.

9. Lowenberg-DeBoer, J. The economics of precision agriculture. In Precision Agriculture for Sustainability; Burleigh Dodds Science Publishing: Cambridge, UK, 2019; pp. 481-1502.

10. Saiz-Rubio, V.; Rovira-Más, F. From smart farming towards agriculture 5.0: A review on crop data management. Agronomy 2020, 10, 207. [CrossRef]

11. Sharma, R.; Kamble, S.S.; Gunasekaran, A.; Kumar, V.; Kumar, A. A systematic literature review on machine learning applications for sustainable agriculture supply chain performance. Comput. Oper. Res. 2020, 119, 104926. [CrossRef]

12. Sozzi, M.; Kayad, A.; Gobbo, S.; Cogato, A.; Sartori, L.; Marinello, F. Economic comparison of satellite, plane and UAV-acquired NDVI images for site-specific nitrogen application: Observations from Italy. Agronomy 2021, 11, 2098. [CrossRef]

13. Bongiovanni, R.; Mantovani, E.; Best, S.; Roel, Á. Introducción a la agricultura de precisión. In Agricultura de Precisión: Integrando Conocimientos para una Agricultura Moderna y Sustentable; Procisur/IICA: Montevideo, Uruguay, 2006.

14. INIAP. Promoviendo una Agricultura Climáticamente Inteligente en la Amazonía; INIAP: Orellana, Ecuador, 2018.

15. Dreher, K. Health and Environmental Impact of Nanotechnology: Toxicological Assessment of Manufactured Nanoparticles. Toxicol. Sci. 2004, 77, 3-5. [CrossRef]

16. Kumar, N.; Kumbhat, S. Essentials in Nanoscience and Nanotechnology; John Wiley \& Sons: Hoboken, NJ, USA, 2016.

17. Khan, I.; Saeed, K.; Khan, I. Nanoparticles: Properties, applications and toxicities. Arab. J. Chem. 2019, 12, 908-931. [CrossRef]

18. Nasrollahzadeh, M.; Sajadi, M.S.; Atarod, M.; Sajjadi, M.; Isaabadi, Z. An Introduction to Green Nanotechnology; Academic Press: Cambridge, MA, USA, 2019.

19. Mousavi, S.; Rezaei, M. Nanotechnology in Agriculture and Food Production. J. Appl. Environ. Biol 2011, 10, 414-419.

20. Rai, M.; Ingle, A. Role of nanotechnology in agriculture with special reference to management of insect pests. Appl. Microbiol. Biotechnol. 2012, 94, 287-293. [CrossRef] [PubMed]

21. Tarafdar, J.C.; Raliya, R.; Mahawar, H.; Rathore, I. Development of Zinc Nanofertilizer to Enhance Crop Production in Pearl Millet (Pennisetum americanum). Agric. Res. 2014, 3, 257-262. [CrossRef]

22. Shalaby, T.A.; Bayoumi, Y.; Abdalla, N.; Taha, H.; Alshaal, T.; Shehata, S.; Amer, M.; Domokos-Szabolcsy, É.; El-Ramady, H. Nanoparticles, soils, plants and sustainable agriculture. In Nanoscience in Food and Agriculture 1; Springer: Cham, Switzerland, 2016; pp. 283-312.

23. Elemike, E.E.; Uzoh, I.M.; Onwudiwe, D.C.; Babalola, O.O. The role of nanotechnology in the fortification of plant nutrients and improvement of crop production. Appl. Sci. 2019, 9, 499. [CrossRef]

24. Luque, A.; Rubiales, D. Nanotechnology for Parasitic Plant Control Pest Management. Sci. J. 2009, 10, $1002-1732$.

25. Alfalahi, A.O.; Abdulqahar, F.W. Nanonutrients: Plant Nutritive and Possible Antioxidant Regulators. In Nanobiotechnology; Springer: Cham, Switzerland, 2021; pp. 471-498.

26. Turan, M.; Sevimli, F. Influence of different nitrogen sources and levels on ion content of cabbage (Brassica oleracea var. capitate). N. Zeal. J. Crop Hortic. Sci. 2005, 33, 241-249. [CrossRef]

27. Xu, Y.; Xiao, Y.; Lagnika, C.; Li, D.; Liu, C.; Jiang, N.; Song, J.; Zhang, M. A comparative evaluation of nutritional properties, antioxidant capacity and physical characteristics of cabbage (Brassica oleracea var. capitate var L.) subjected to different drying methods. Food Chem. 2020, 309, 124935. [CrossRef]

28. Petit, G. HOR09-08. Comportamiento y Desempeño de Seis Cultivares de Repollo (Brassica olereacea L. var capitata) Cultivados en el Valle de Comayagua; Programa de Hortalizas, FHIA: Comayagua, Honduras, 2009.

29. Song, X.; Li, Y.; Hou, X. Genome-wide analysis of the AP2/ERF transcription factor superfamily in Chinese cabbage (Brassica rapa ssp. pekinensis). BMC Genom. 2013, 14, 1-15. [CrossRef] 
30. Šamec, D.; Pavlović, I.; Salopek-Sondi, B. White cabbage (Brassica oleracea var. capitata f. alba): Botanical, phytochemical and pharmacological overview. Phytochem. Rev. 2017, 16, 117-135.

31. Ramos, M. Cultivo de Repollo en México (Brassica oleracea L.) var. Capitata L.; UAAAN: Santillo, México, 2007.

32. Kong, C.; Chen, G.; Yang, L.; Zhuang, M.; Zhang, Y.; Wang, Y.; Ji, J.; Fang, Z.; Lv, H. Germplasm screening and inheritance analysis of resistance to cabbage black rot in a worldwide collection of cabbage (Brassica oleracea var. capitata) resources. Sci. Hortic. 2021, 288, 110234. [CrossRef]

33. Guambo, M. Estudio Bioagronómico de 20 Cultivares de Col (Brassica oleracea L. var. capitta); ESPOCH, Recursos Humanos: Riobamba, Ecuador, 2010.

34. Simons, A. The Healing Power of Plants: Medical Plants from Abuta and Acerola to Yohimbe and Yucca: A Practical Selection; MayaMedia Verlag: Falkensee, Germany, 2013.

35. Bartram, T. Bartram's Encyclopedia of Herbal Medicine; Hachette: Paris, France, 2013; ISBN 13: 978-1-85487-586-0.

36. Gupta, S.G.; Ghonge, M.M.; Jawandhiya, P.M. Review of unmanned aircraft system (UAS). Int. J. Adv. Res. Comput. Eng. Technol. (IJARCET) 2013, 2, 1646-1658. [CrossRef]

37. Colomina, I.; Molina, P. Unmanned aerial systems for photogrammetry and remote sensing: A review. ISPRS J. Photogramm. Remote Sens. 2014, 92, 79-97. [CrossRef]

38. Siebert, S.; Teizer, J. Mobile 3D mapping for surveying earthwork projects using an Unmanned Aerial Vehicle (UAV) system. Autom. Constr. 2014, 41, 1-14. [CrossRef]

39. Kyrkou, C.; Timotheou, S.; Kolios, P.; Theocharides, T.; Panayiotou, C. Drones: Augmenting our quality of life. IEEE Potentials 2019, 38, 30-36. [CrossRef]

40. Berni, J.; Suarez, L.; Zarco-Tejada, P.; Fereres, E. Thermal and Narrowband Multispectral Remote Sensing for Vegetation Monitoring From an Unmanned Aerial Vehicle. IEEE Trans. Geosci. Remote Sens. 2009, 47, 722-738. [CrossRef]

41. Krzysztof, B. Secrets of UAV Photomapping. Presented Satellite Maps. 2011. Available online: file:///C:/Users/MDPI/ AppData/Local/Temp/BosaksecretsofUAVphotomapping.pdf (accessed on 14 November 2021).

42. Aasen, H.; Burkart, A.; Bolten, A.; Bareth, G. Generating 3D hyperspectral information with lightweight UAV snapshot cameras for vegetation monitoring: From camera calibration to quality assurance. ISPRS J. Photogramm. Remote Sens. 2015, 108, 245-259. [CrossRef]

43. Portero, C.; Salas, P.; Mercadal, M.; Casterad, M. Experiencias en la adquisición de imágenes para agricultura a empresas de drones españolas. In Nuevas Plataformas y Sensores de Teledetección. XVII Congreso de la Asociación Española de Teledetección; Editorial Politécnica de Valencia: Zaragoza, Spain, 2017; pp. 461-464.

44. Kayad, A.; Sozzi, M.; Gatto, S.; Marinello, F.; Pirotti, F. Monitoring within-field variability of corn yield using Sentinel-2 and machine learning techniques. Remote Sens. 2019, 11, 2873. [CrossRef]

45. Morgan, M.; Shanahan, J.; Signorielli, N. Yesterday's new cultivation, tomorrow. Mass Commun. Soc. 2015, 18, 674-699. [CrossRef]

46. Ponzoni, F.J.; Pacheco, L.R.F.; dos Santos, S.B.; Andrades Filho, C.D.O. Caracterização espectro-temporal de dosséis de Eucalyptus spp. mediante dados radiométricos TM/Landsat5. Cerne 2015, 21, 267-275. [CrossRef]

47. Körner, C. Scaling from species to vegetation: The usefulness of functional groups. In Biodiversity and Ecosystem Function; Springer: Berlin/Heidelberg, Germany, 1994; pp. 117-140.

48. Xue, J.; Su, B. Significant Remote Sensing Vegetation Indices: A Review of Developments and Applications. J. Sens. 2017, 2017, 1353691. [CrossRef]

49. Jamaludin, M.I.; Matori, A.N.; Kholik, M.F.; Mokhtar, M.M. Development Spectral Library of Vegetation Stress for Hydrocarbon Seepage. Appl. Mech. Mater. 2014, 567, 693-698. [CrossRef]

50. Okada, Y.; Maeno, E. Apoptosis, cell volume regulation and volume-regulatory chloride channels. Comp. Biochem. Physiol. Part A Mol. Integr. Physiol. 2001, 130, 377-383. [CrossRef]

51. Shanahan, J.F.; Schepers, J.S.; Francis, D.D.; Varvel, G.E.; Wilhelm, W.W.; Tringe, J.M.; Schlemmer, M.R.; Major, D.J. Use of remote-sensing imagery to estimate corn grain yield. Agron. J. 2001, 93, 583-589. [CrossRef]

52. Moges, S.M.; Raun, W.R.; Mullen, R.W.; Freeman, K.W.; Johnson, G.V.; Solie, J.B. Evaluation of green, red, and near infrared bands for predicting winter wheat biomass, nitrogen uptake, and final grain yield. J. Plant Nutr. 2005, 27, 1431-1441. [CrossRef]

53. Babar, M.A.; Reynolds, M.P.; Van Ginkel, M.; Klatt, A.R.; Raun, W.R.; Stone, M.L. Spectral reflectance to estimate genetic variation for in-season biomass, leaf chlorophyll, and canopy temperature in wheat. Crop Sci. 2006, 46, 1046-1057. [CrossRef]

54. Jiang, L.; Kogan, F.N.; Guo, W.; Tarpley, J.D.; Mitchell, K.E.; Ek, M.B.; Tian, Y.; Zheng, W.; Zou, C.Z.; Ramsay, B.H. Real-time weekly global green vegetation fraction derived from advanced very high resolution radiometer-based NOAA operational global vegetation index (GVI) system. J. Geophys. Res. Atmos. 2010, 115, D11. [CrossRef]

55. Pettorelli, N.; Ryan, S.; Mueller, T.; Bunnefeld, N.; Jędrzejewska, B.; Lima, M.; Kausrud, K. The Normalized Difference Vegetation Index (NDVI): Unforeseen successes in animal ecology. Clim. Res. 2011, 46, 15-27. [CrossRef]

56. Khaleghi, E.; Arzani, K.; Moallemi, N.; Barzegar, M. Evaluation of chlorophyll content and chlorophyll fluorescence parameters and relationships between chlorophyll $\mathrm{a}, \mathrm{b}$ and chlorophyll content index under water stress in Olea europaea cv. Dezful. World Acad. Sci. Eng. Technol. 2012, 6, 1154-1157.

57. Eastman, J.R.; Sangermano, F.; Machado, E.A.; Rogan, J.; Anyamba, A. Global trends in seasonality of normalized difference vegetation index (NDVI) 1982-2011. Remote Sens. 2013, 5, 4799-4818. [CrossRef] 
58. Hunt Jr, E.R.; Doraiswamy, P.C.; McMurtrey, J.E.; Daughtry, C.S.; Perry, E.M.; Akhmedov, B. A visible band index for remote sensing leaf chlorophyll content at the canopy scale. Int. J. Appl. Earth Obs. Geoinf. 2013, 21, 103-112. [CrossRef]

59. Caseras, I. Seguimiento de Viñas Mediante Imágenes Multiespectrales Aéreas y de Satélite; Univesidad Pública de Navarra: Navarra, España, 2017.

60. Liu, C.; Liu, Y.; Lu, Y.; Liao, Y.; Nie, J.; Yuan, X.; Chen, F. Use of a leaf chlorophyll content index to improve the prediction of above-ground biomass and productivity. PeerJ 2019, 6, e6240. [CrossRef]

61. Zuñiga, C.; Sankaran, S.; Khot, L.; Jacoby, P. High Resolution Multispectral and Thermal Remote Sensing-Based Water Stress Assessment in Subsurface Irrigated Grapevines. Remote Sens. Agric. Veg. 2017, 9, 961. [CrossRef]

62. Bendig, J.; Bolten, A.; Bennertz, S.; Broscheit, J.; Eichfuss, S.; Bareth, G. Estimating Biomass of Barley Using Crop Surface Models (CSMs) Derived from UAV-Based RGB Imaging. Remote Sens. 2014, 6, 10395-10412. [CrossRef]

63. Karpina, M.; Jarząbek-Rychard, M.; Tymków, P.; Borkowski, A. UAV-based automatic tree growth measurement for biomass estimation. Int. Arch. Photogramm. Remote Sens. Spat. Inf. Sci. 2016, 8, 685-688. [CrossRef]

64. Devia, C.A.; Rojas, J.P.; Petro, E.; Martinez, C.; Mondragon, I.F.; Patiño, D.; Rebolledo, M.C.; Colorado, J. High-throughput biomass estimation in rice crops using UAV multispectral imagery. J. Intell. Robot. Syst. 2019, 96, 573-589. [CrossRef]

65. Gil-Docampo, M.; Arza, M.; Ortiz, J.; Martínez, S.; Robles, M.; Sánchez, L. Above-ground biomass estimation of arable crops using UAV-based SfM photogrammetry. Geocarto Int. 2020, 35, 687-699. [CrossRef]

66. Sinde-González, I.; Gil-Docampo, M.; Arza-García, M.; Grefa-Sánchez, J.; Yánez-Simba, D.; Pérez-Guerrero, P.; Abril-Porras, V. Biomass estimation of pasture plots with multitemporal UAV-based photogrammetric surveys. Int. J. Appl. Earth Obs. Geoinf. 2021, 101, 102355. [CrossRef]

67. Gutiérrez, H.; De la Vara, R. Análisis y Diseño de Experimentos; Segunda, Ed.; McGraw-Hill: Mexico City, México, 2008.

68. Chuvieco, E. Principios físicos de la Teledetección. In Fundamentos de Teledetección Espacial; Ediciones Rialp.S.A.: Madrid, España, 1990; pp. 45-50.

69. Qi, J.; Chehbouni, A.; Huete, A.R.; Kerr, Y.H.; Sorooshian, S. A modified soil adjusted vegetation index. Remote Sens. Environ. 1994, 48, 119-126. [CrossRef]

70. Houborg, R.; Soegaard, H.; Boegh, E. Combining vegetation index and model inversion methods for the extraction of key vegetation biophysical parameters using Terra and Aqua MODIS reflectance data. Remote Sens. Environ. 2007, 106, 39-58. [CrossRef]

71. Moncayo Cevallos, L.N.; Andrade Suárez, B.I.; Sinde González, I.; Maiguashca Guzmán, J.A.; Rivadeneira García, J.L.; Leiva González, C.A.; Yépez Campoverde, J.A.; Toulkeridis, T. A NDVI analysis contrasting different spectrum data methodologies applied in pasture crops previous grazing-A case study from Ecuador. In Proceedings of the 2018 th International Conference on eDemocracy and eGovernment, ICEDEG 2018, Ambato, Ecuador, 4-6 April 2018; pp. 126-135.

72. Viera-Torres, M.; Sinde-González, I.; Gil-Docampo, M.; Bravo, V.; Toulkeridis, T. Generation of the base line in the early detection of bud rot and the red ring disease in oil palms by geospatial technologies. Remote Sens. 2020, 12, 3229. [CrossRef]

73. Mora Villacís, M.G.; Cañarte Ruiz, D.A.; Kirby, E.; Maiguashca Guzmán, J.A.; Toulkeridis, T. Index Relationship of Vegetation with the Development of a Quinoa Crop (Chenopodium quinoa) in its First Phenological Stages in Central Ecuador Based on GIS Techniques. In Proceedings of the 2020 7th International Conference on eDemocracy and eGovernment, ICEDEG 2020, Buenos Aires, Argentina, 22-24 April 2020; pp. 190-199.

74. Cañarte Ruiz, D.A.; Mora Villacís, M.G.; Kirby, E.; Maiguashca Guzmán, J.A.; Toulkeridis, T. Correlation of NDVI Obtained by Different Methodologies of Spectral Data Collection in a Commercial Crop of Quinoa (Chenopodium quinoa) in Central Ecuador. In Proceedings of the 2020 7th International Conference on eDemocracy and eGovernment, ICEDEG 2020, Buenos Aires, Argentina, 22-24 April 2020; pp. 207-214.

75. Liu, J.; Pattey, E.; Jégo, G. Assessment of vegetation indices for regional crop green LAI estimation from Landsat images over multiple growing seasons. Remote Sens. Environ. 2012, 123, 347-358. [CrossRef]

76. Gutiérrez, M.; Escalante, J.; Rodríguez, M.; Reynolds, M. Índices de reflectancia y rendimiento del frijol con aplicaciones de nitrógeno. Terra Latinoam. 2004, 22, 409-416.

77. Tucker, C. Red and photographic infrared linear combinations for monitoring vegetation. Remote Sens. Environ. 1979, 8, 127-150. [CrossRef]

78. Díaz, J. Estudio de Índices de Vegetación a Partir de Imágenes Aéreas Tomadas Desde UAS/RPAS y Aplicaciones de Estos a la Agricultura de Precisión; UCM: Madrid, España, 2015.

79. Lira, R.; Méndez, B.; De los Santos, G.; Vera, I. Potencial de la nanotecnología en la agricultura. Acta Univ. 2018, $28,16$.

80. Gitelson, A.; Kaufman, Y.; Merzlyak, M. Use of a green channel in remote sensing of global vegetation from EOS-MODIS. Remote Sens. Environ. 1996, 58, 289-298. [CrossRef]

81. Hoffmann, H.; Rasmus, J.; Thomsen, A.; Nieto, H.; Rasmussen, J.; Friborg, T. Crop water stress maps for an entire growing season from visible and thermal UAV imagery. Biogeosciences 2016, 13, 6548. [CrossRef]

82. Yang, C.; Liu, T.-X.; Everitt, J.H. Estimating cabbage physical parameters using remote sensing technology. Crop Prot. 2008, 27, 25-35. [CrossRef]

83. Bracke, J.; Elsen, A.; Adriaenssens, S.; Vandendriessche, H.; Van Labeke, M.C. Utility of proximal plant sensors to support nitrogen fertilization in Chrysanthemum. Sci. Hortic. 2019, 256, 108544. [CrossRef] 
84. Acharya, A.; Pal, P.K. Agriculture nanotechnology: Translating research outcome to field applications by influencing environmental sustainability. NanoImpact 2020, 19, 100232. [CrossRef]

85. Torres-Sánchez, J.; López-Granados, F.; De Castro, A.I.; Peña-Barragán, J.M. Configuration and specifications of an unmanned aerial vehicle (UAV) for early site specific weed management. PloS ONE 2013, 8, e58210. [CrossRef] [PubMed]

86. Raj, R.; Kar, S.; Nandan, R.; Jagarlapudi, A. Precision agriculture and unmanned aerial Vehicles (UAVs). In Unmanned Aerial Vehicle: Applications in Agriculture and Environment; Springer: Cham, Switzerland, 2020; pp. 7-23.

87. Jannoura, R.; Brinkmann, K.; Uteau, D.; Bruns, C.; Joergensen, R.G. Monitoring of crop biomass using true colour aerial photographs taken from a remote controlled hexacopter. Biosyst. Eng. 2015, 129, 341-351. [CrossRef]

88. Chappelle, E.W.; Kim, M.S. Ratio Analysis of Reflectance Spectra (RARS): An Algorithm for the Remote Estimation of the Concentrations of Chlorophyll A, Chlorophyll B, and Carotenoids in Soybean Leaves. Teledetección Medio Ambiente 1992, 39 , 239-247. [CrossRef]

89. López, G.; Méndez, B.; Lira, R. Medición de Intercambio Gaseoso, Área Foliar e Índice de Clorofila en Plantas Elicitadas con Nanopartículas. In Agronano Tecnología: Nueva Frontera de la Revolución Verde; CIQA: Mexico City, México, 2016; pp. 112-128.

90. Tarafdar, J.C.; Adhikari, T.A.P.A.N. Nanotechnology in soil science. In Soil Science: An Introduction, Chapter: Nanotechnology in Soil Science; Melbourne University Publishing: Melbourne, Australia, 2015; pp. 775-807.

91. Kwak, D.-A.; Lee, W.-K.; Cho, H.-K.; Lee, S.-H.; Son, Y.; Kafatos, M.; Kim, S.-R. Estimating stem volume and biomass of Pinus koraiensis using LiDAR data. J. Plant Res. 2010, 123, 421-432. [CrossRef] 